\title{
COMENTÁRIO:
}

\section{O CONATUS É SEMPRE IMAGINATIVO}

\author{
Fernando Dias Andrade ${ }^{1}$
}

Referência do artigo comentado: RODRIGUES, J. L. O conatus imaginativo em Espinosa: a produção da contingência e da ideia de finalidade. Trans/Form/Açáa: revista de filosofia da Unesp, vol. 44, n. 1, p. 205-244, 2021.

$\mathrm{O}$ excelente artigo de Rodrigues (2021) - alguém que tem plena familiaridade com os meandros da Ética de Espinosa - instiga-me pelo menos às seguintes ponderaçóes.

Parto de uma afirmação de Rodrigues (2021, p. 222), em suas consideraçóes finais: "[...] o desconhecimento da lógica do conatus, que envolve a produção das paixões, é responsável pela ilusão da escolha livre ou indeterminada.”

De fato, essa afirmação é apropriada para indicar o centro da argumentação do artigo: o conatus, essência atual não só do homem como de tudo o que é dado no real, ao menos no que nos envolve, é sempre expressão, também, do nosso desejo atual, ou seja, do apetite de que se tem consciência, o qual, por jamais ser simples, isto é, por sempre ser composição de afetos distintos e mesmo contrários - em suma, alegrias e tristezas múltiplas e simultâneas -, faz com que o sujeito afetivo por vezes seja tomado simultaneamente de amor ou de ódio por um mesmo objeto, condição que por si mesma fá-lo afetar-se

${ }^{1}$ Livre-Docente em Filosofia pela Universidade Federal de São Paulo (Unifesp) e Professor Associado III de História da Filosofia Universidade Federal de São Paulo (Unifesp), São Paulo, SP - Brasil.

(D) https://orcid.org/0000-0002-7874-198X E-mail: f.d.andrade@outlook.com

https://doi.org/10.1590/0101-3173.2021.v44n1.16.p229 
de flutuação de ânimo, a qual não é afeto, mas constituição contraditória da mente instalada a partir da simultaneidade de afetos contrários (ESPINOSA, 2015, EIII, P17, escólio, p. 265), confunde a intelecção de suas próprias causas, instala a dúvida na mente - cuja causa é, portanto, afetiva e não racional - e, em conseqüência, intensifica a atividade da imaginação, por força da qual alguém é levado a imaginar confusamente a causa das açóes que se dirijam ao objeto que o afeta simultaneamente de amor e ódio. Por força de uma percepção confusa que a flutuaçáo de ânimo opera em nós, não percebemos distintamente nem a causa da alegria apenas nem a da tristeza apenas, e, atordoados por tal confusão, não inteligimos o caráter necessário do que confusamente nos parecerá escolha livre tomada acerca daquilo que nos produziu no ânimo da flutuação.

Noutras palavras, temos o hábito de imaginar que as escolhas que enunciamos são livres, quer dizer, que não seriam determinadas por algo externo ao que é por nós imaginado ser nossa vontade. Porém, não possuímos essa vontade imaginada habitualmente como vontade livre, ou seja, faculdade apta à livre escolha entre opçóes imaginadas como possíveis. Ademais, não existem realmente, como possíveis, tais opções assim imaginadas. A imaginação, atividade pensante necessariamente presente em nós, a despeito de suas potências peculiares, é aqui relevante em função de suas impotências: por ser fonte de confusão, a imaginação se mostra um instrumento inseguro para a produção do conhecimento. É imaginativa a noção da existência de possíveis, assim como o é a noção de que são livres nossas escolhas conscientes, ou nossa noção de que é vontade nossa faculdade de escolha, ou nossa noção de que nossa ação pode ser independente de causas afetivas ou passionais quaisquer. Porque necessariamente imaginamos, habitualmente confundimo-nos e obstamos uma adequada intelecção das causas de nossas próprias açóes, quer corpóreas, quer mentais.

Tal confusão perceptiva, ainda que nos engane, não impede a ocorrência da causalidade afetiva complexa que nos atinge em ato, muito menos seus efeitos, os quais incluem alegrias e tristezas contrárias entre si e simultaneamente pertinentes a objeto ao qual não somos indiferentes. Se, aí, estamos confundidos quanto à causa de nossas açóes é porque fomos, já que o desejo é nossa essência atual, confundidos quanto à causa de nossos afetos - mormente se forem, como no caso são, contrários e simultâneos. A consequência é a flutuação de ânimo, essa hesitação afetiva entre contrários, que mentalmente se desdobra em futuação de imaginação, estado de perplexidade imaginativa tão bem denunciado por Marilena Chauí e aqui recuperado em momento preciso por Juarez Rodrigues. 
Se a flutuação de ânimo é, de fato, condição inevitável em nossas existências - afinal, como não percebê-la em si mesma, enquanto não se vislumbra a saída para fora de uma contradição afetiva? -, o que é mais relevante para o filósofo é o risco, daí derivado, de incorrer na flutuação de imaginação, que, por sua vez, instala em nossa mente o hábito da dúvida irracional, a ser alimentada pelo insano gosto pela inconsistência, pela falsidade ou mesmo pela mentira.

Busca o artigo, diante desse desequilíbrio relacionado às flutuações de ânimo e de imaginação, recuperar certa potência da imaginação, ao tratar do conatus - esforço que todo ser tem pela autopreservação - como atividade imaginativa. Apesar de a imaginação promover uma percepção confusa da causalidade a vincular afetos contrários entre si - o que torna perplexo o indivíduo afetado simultaneamente por tal contradição afetiva -, a mesma imaginação pode auxiliar na percepção da necessidade de cada um dos afetos, se percebidos singularmente, pois tanto a alegria singular quanto a tristeza singular que ali lhe confronta são expressão de conatus do indivíduo afetado por elas, e tal expressão pode ser tida como já evidenciada pela imaginação.

Ou seja: ainda que estejamos tomados de flutuaçáo de ânimo, imaginamos, ou a tal somos aptos, como expressão de nosso desejo atual, tanto a alegria, que ao desejo é conforme, quanto a tristeza, que, embora contrária ao desejo, faz-nos intensificar o desejo. O conatus, portanto, tem uma expressão imaginativa, que, a despeito de ser imaginativa, é evidência de afirmação de si. Tal positividade do conatus, perceptível também imaginativamente, dá à imaginação igualmente o papel de potência atual de reequilíbrio, desde que esteja o indivíduo potente o bastante para reagir à flutuação de imaginação com uma imaginação atenta ao próprio desejo.

O desejo, tal como o define Espinosa, é o apetite de que se tem consciência. Essa consciência é, desde o início, pelo menos consciência imaginativa, percepção consciente imaginativa do próprio conatus. Confundida todavia tal percepção, confunde-se ou oblitera-se a correspondente consciência e, apesar do desejo ativo, confrontar-se-á com ele um estado imaginativo contrário - a flutuação de imaginação.

Dado que o desejo, porém, sempre é o apetite de que se tem consciência, importa ter sempre em mente o que é o apetite. Como Espinosa define o apetite? Conforme EIII, P9, escólio (ESPINOSA, 2015, p. 253), o apetite é o próprio esforço de autoconservação enquanto é referido simultaneamente à mente e ao corpo. Tal definição é útil para diferenciar o apetite, real, da vontade, apenas 
imaginativa, pois que definida como ente quimérico, já que seria o esforço de autopreservação enquanto referido só à mente (algo impossível, já que a mente é idéia do corpo e, portanto, é impossível conceber a existência real da mente, sem se conceber simultaneamente a existência real do corpo de que é idéia a mente.

Noutras palavras: ser o conatus consciência de apetite implica ser consciência de que o esforço atual de autopreservação se dá simultaneamente na mente e no corpo, e, porque nunca o corpo está fora da expressividade do conatus e porque sempre a imaginação exprime também uma atividade sensível do corpo, é sempre igualmente imaginativo o conatus.

Não há negatividade no caráter imaginativo em si do conatus. O que promove o desequilíbrio no indivíduo imaginante é, em caso de perplexidade, a queda num estado de flutuação imaginativa. Trata-se de evitar esta, o que depende em parte do fortalecimento da própria imaginaçáo, a partir de algum tipo de educação imaginativa que habitue a imaginação a não se confundir, no que respeita aos próprios apetites. A percepção imaginativa dos próprios apetites, se produzida num indivíduo composto de mente e corpo em equilíbrio, suporta sem danos relevantes a contradição entre afetos, pois de cada um percebe simultaneamente a necessidade do apetite e se alegra, portanto, tanto a partir da alegria quanto da tristeza que aquela confronta. $\mathrm{O}$ resultado, no indivíduo equilibrado, será não a flutuação de imaginação - nem sequer, talvez, a flutuação de ânimo -, mas a alegre percepção imaginativa da realidade necessária dos apetites atualmente imaginados independentemente de, também, poderem ser adequadamente inteligidos.

Da flutuação de ânimo assombrada miseravelmente por uma flutuação de imaginação, vislumbra-se, pois, uma recuperação de dignidade para a imaginação, tanto quanto se evidencie que a lógica do conatus é meio para atentarmos à realidade dos nossos apetites como expressáo do inseparável esforço de autopreservaçáo de nosso corpo e de nossa mente.

\section{REFERÊNCIAS}

ESPINOSA, B. Ética. Tradução do Grupo de Estudos Espinosanos; coordenação de Marilena Chaú. São Paulo: Editora da Universidade de São Paulo, 2015.

RODRIGUES, J. L. O conatus imaginativo em Espinosa: a produção da contingência e da ideia de finalidade. Trans/Form/Açáo: revista de filosofia da Unesp, v. 44, n. 1, p. 205-224, 2021.

Recebido: 08/11/2020

Aceito: 14/11/2020 